\title{
A máj VII-es szegmentumában igazolt áttéti daganat laparoszkópos reszekciója
}

\author{
Dede Kristóf dr. ${ }^{1}$ - Papp Géza dr. ${ }^{1}$ - Salamon Ferenc dr. ${ }^{2}$ \\ Uhlyarik Andrea dr. ${ }^{3}$ - Bursics Attila dr. ${ }^{1}$ \\ Uzsoki Utcai Kórház, ${ }^{1}$ Sebészeti, Onkosebészeti Osztály, ${ }^{2}$ Patológiai Osztály, Budapest \\ ${ }^{3}$ Magyar Honvédség Egészségügyi Központ, Onkológiai Osztály, Budapest
}

\begin{abstract}
A májsebészet technikája és eredményei folyamatosan fejlődnek az utóbbi években, amely fejlődés talán legintenzívebben a laparoszkópos májsebészet területén érezhető. Az eddig közölt összehasonlító vizsgálatok alapján a laparoszkópos mútétek eredményei nem maradnak el a nyílt mútétek eredményeitől. Bár a májreszekciók igen kis százalékát végzik laparoszkóposan, a minimálisan invazív reszekciós technikának egyértelmúen helye van az onkológiai sebészet területén. A minor, a major, az anatómiai vagy éppen a többszakaszos májreszekciók is elvégezhetők laparoszkóposan, és a korábban általános ajánlás, amely szerint az elöl fekvő szegmentumokban javasolható a minimálisan invazív technika, jelenleg már túlhaladott. A szerzők egy 70 éves nőbeteg esetét mutatják be, akinél rectumdaganat komplex onkosebészeti kezelését követően a máj VII-es szegmentumában kialakult metasztázis miatt végeztek laparoszkópos májreszekciót. Az esetismertetéssel a szerzők arra kívánnak rávilágítani, hogy a hátsó szegmentumok malignus elváltozásai is biztonsággal megközelíthetook és eltávolíthatók laparoszkóppal. Orv. Hetil., 2016, 157(20), 796-800.
\end{abstract}

Kulcsszavak: májreszekció, laparoszkópia, onkológiai sebészet

\section{Laparoscopic resection of a liver metastasis from segment VII}

\section{Case report}

\begin{abstract}
The technique and clinical results of liver surgery are constantly evolving in recent years, and this development felt most intensely in the field of laparoscopic liver surgery. Based on the results of comparative studies reported to date, laparoscopic surgery is not inferior to open surgery. Although a very small percentage of liver resections are performed with laparoscopic technique, clearly it has a role in oncological surgery. The minor, major, anatomical, or even multi-stage liver resections can be performed with laparoscopy. The previously general recommendation, that lesions in the front segments of the liver are recommended for the minimally invasive technique is currently outdated. The authors present the history of a 70-year-old female, who underwent complex oncosurgical treatment of a locally advanced rectum carcinoma and a pure laparoscopic resection of a solitary hepatic metastasis of segment VII. With this case report the authors want to underline that malignant lesions in the posterior segments of the liver can be removed safely with laparoscopy.
\end{abstract}

Keywords: liver resection, laparoscopy, surgical oncology

Dede, K., Papp, G., Salamon, F., Uhlyarik, A., Bursics, A. [Laparoscopic resection of a liver metastasis from segment VII. Case report]. Orv. Hetil., 2016, 157(20), 796-800.

(Beérkezett: 2016. február 21.; elfogadva: 2016. március 19.)

\section{Rövidítések}

ALPPS = (associating liver partition and portal pein ligation for staged hepatectomy) a májfelosztás és a májkapuvéna-lekötés összekapcsolása a szakaszos májeltávolításban; HALS = (handassisted laparoscopic surgery) kézzel asszisztált laparoszkópos sebészet
A laparoszkópos sebészet kezdeti időszakából, az 1990es évekből is vannak már irodalmi hivatkozások a máj minimálisan invazív reszekciójáról, mégis az utóbbi évtizedben kezdődött a laparoszkópia térnyerése a májsebészetben [1-4]. Magyarországon is vannak már hazai betegek adatait feldolgozó közlések, de ezek jóindulatú 
elváltozások laparoszkópos reszekciójáról számolnak be $[5,6]$. Malignus májelváltozások laparoszkópos reszekciójáról eddig összefoglaló közlemény jelent meg 2014ben [7].

A világon több májsebészeti centrumban végeznek rutinszerúen laparoszkópos reszekciókat, azonban ezen mütétek aránya az összes májreszekciót tekintve továbbra is alacsony. Létezik tisztán laparoszkópos, „handassisted" és a hibrid technika, amelyek közül a két utóbbit legtöbben a nehéz, komplikált eseteknél javasolják alkalmazni [8, 9]. Annak ellenére, hogy míg kezdetben csak az elöl fekvő szegmentumok esetében ajánlották a laparoszkópos technikát, mára minden szegmentum megközelítésére létezik kidolgozott technika, illetve a nagyobb anatómiai reszekciók is biztonsággal kivitelezhetők [10-14]. Ezenkívül extremitásnak tekinthető próbálkozások is vannak, mint a felsőbb szegmentumok thoracolaparoszkópos megközelítése, a laparoszkópos ALPPS-mütét vagy például a „single incision” májreszekció [15-17]. A robotasszisztált májreszekciók és a laparoszkópos májreszekciók összehasonlító tanulmányai is közlésre kerültek már [18, 19].

Közleményünkben egy, a máj nehezen megközelíthető szegmentumából tisztán laparoszkóposan eltávolított áttéti daganat esetismertetésén keresztül kívánjuk bemutatni a technikai igényeket és lehetőségeket, valamint a megbeszélésben vázolni a laparoszkópia helyét a májsebészetben.

\section{Esetismertetés}

A 70 éves nóbetegnél stenotizáló rectum-adenocarcinomát igazoltak. Semiurgens jelleggel mütétre kényszerültek más intézetben, a kismedencében irreszekábilisnak véleményezett viszonyok miatt tehermentesítő sigmoideostomiát készítettek. Ezt követően a beteg sugár- és kemoterápiában részesült. A kontroll képalkotó vizsgálaton jelentős regressziót véleményeztek a primer tumor vonatkozásában, azonban szoliter hepaticus áttétet is igazoltak. Osztályunkon ismételt mútét történt, amely során anterior reszekciót végeztünk hysterectomiával és kétoldali adnexectomiával, zártuk a sigmoideostomát. Szövődménymentes gyógyulást követően, az ismételten összehívott oncoteam véleménye alapján, a reszekábilis májáttét eltávolítását terveztük elsőként, majd adjuváns kezelést javasoltunk (1. ábra). A rectumreszekciót követően 8 héttel a kontroll képalkotó vizsgálaton stacioner elváltozást tisztán laparoszkópos módszerrel reszekáltuk.

A mütét menete (2. ábra): A beteget zárt lábbal, háton fekve, a jobb oldalon körülbelül 30 fokkal kiemelve pozicionáltuk. Az operatőr a beteg jobb oldalán, az asszisztensek a beteg bal oldalán álltak. Nyílt technikával történt az insufflálás a medioclavicularis vonalban a felhas középső részén, ide került a kamera egy 10 mm-es trokáron keresztül. Ettől jobbra lateralisan került behelyezésre egy $11 \mathrm{~mm}$-es múanyag trokár és egy $5 \mathrm{~mm}$-es munkatrokár

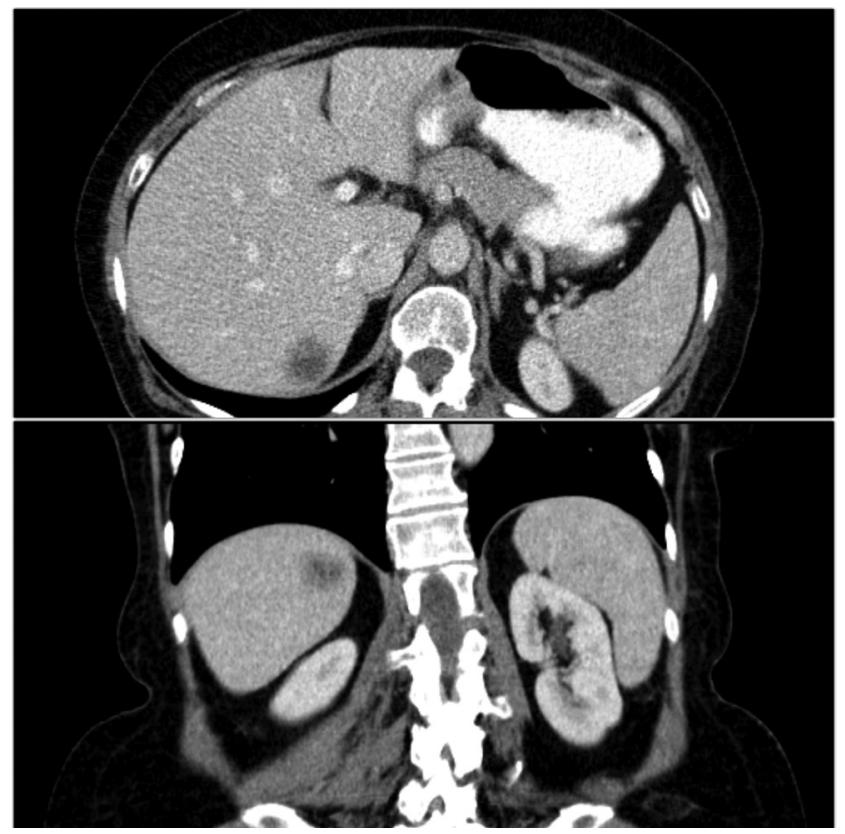

1. ábra | Műtét előtti CT-felvétel a májban észlelt metasztázisról

a bordaív vonalában. A felső medián vonaltól jobbra egy 10 mm-es trokáron keresztül vezettük be a májretraktort. A máj jobb lebenyének mobilizálásával kezdtük a műtétet, amely során a vena cava inferior mellett haladva, valamint a lig. triangulare hepatis preparálásával jutottunk el a jobb vena hepatica és vena cava inferior szögletig. A kis direkt vénákat vágó-koaguláló eszközzel, illetve fémklipekkel láttuk el. Ezt követően a kirekesztés előkészítéséhez vastag gumi segítségével kétszer átfüzve felvettük a lig. hepatoduodenalét és műanyag klipekkel biztosítottuk. A has középvonalának felső harmadában egy 5 mmes trokárt helyeztünk be, hogy a máj vascularis kirekesztéséhez meg lehessen húzni a gumit. A 12 mm-es trokáron keresztül intraoperatív ultrahangvizsgálatot végeztünk (Toschiba Xario 200), és kijelöltük a reszekciós széleket a máj felszínén minden irányban. A megfelelő síkot a reszekció menete során többször ellenőriztük. A reszekciót a nyílt mútétekhez hasonlóan nagy energiájú vágó-koaguláló eszközzel végeztük, a jelentősebb portalis és vénás képletekre fémklipet helyeztünk. 14 és 11 perces vascularis exclusiót alkalmaztunk 5 perces szünettel. A reszekciós felszínt ezt követően szintén a 11 mm-es trokáron keresztül könnyen behelyezhető longetták segítségével kontrolláltuk, elektrokoagulációval csillapítottuk a kisebb vérzéseket. Varrógépet nem használtunk. Drént a medioclavicularis vonalban vezettünk be. A speciment endobagben távolítottuk el a kamera portjának meghosszabbított metszéséből.

A drént a posztoperatív 3. napon távolítottuk el, a beteget az 5. posztoperatív napon emittáltuk. A specimen feldolgozása során R0 reszekció igazolódott, legközelebbi reszekciós szél 5,2 mm (3. ábra). 


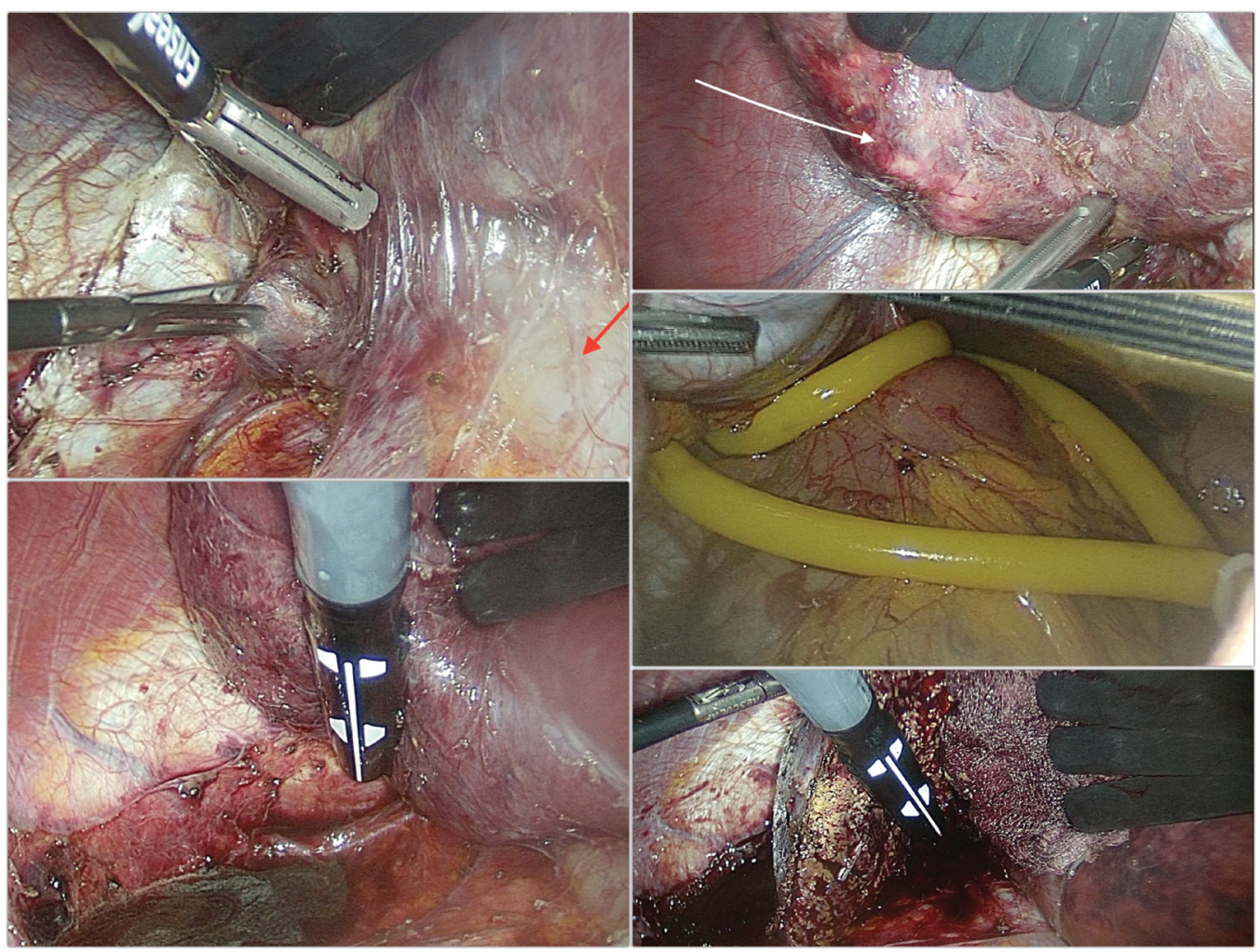

2. ábra

Mútéti képek: a máj teljes jobb lebenyének mobilizálása, nyíllal jelölve a v. cava inferior (balra fönt), a máj felszínén fehér nyíllal jelölve látható a metasztázis (jobbra fönt), a ligamentum hepatoduodenale elókészítése a máj vascularis kirekesztésére (jobbra középen), a tumor lokalizálása, a környező képletek identifikálása és a reszekciós szél kijelölése intraoperatív ultrahang segítségével (balra lent), a reszekció közben a reszekciós szél és a tumorlokalizáció kontrollja (jobbra lent)
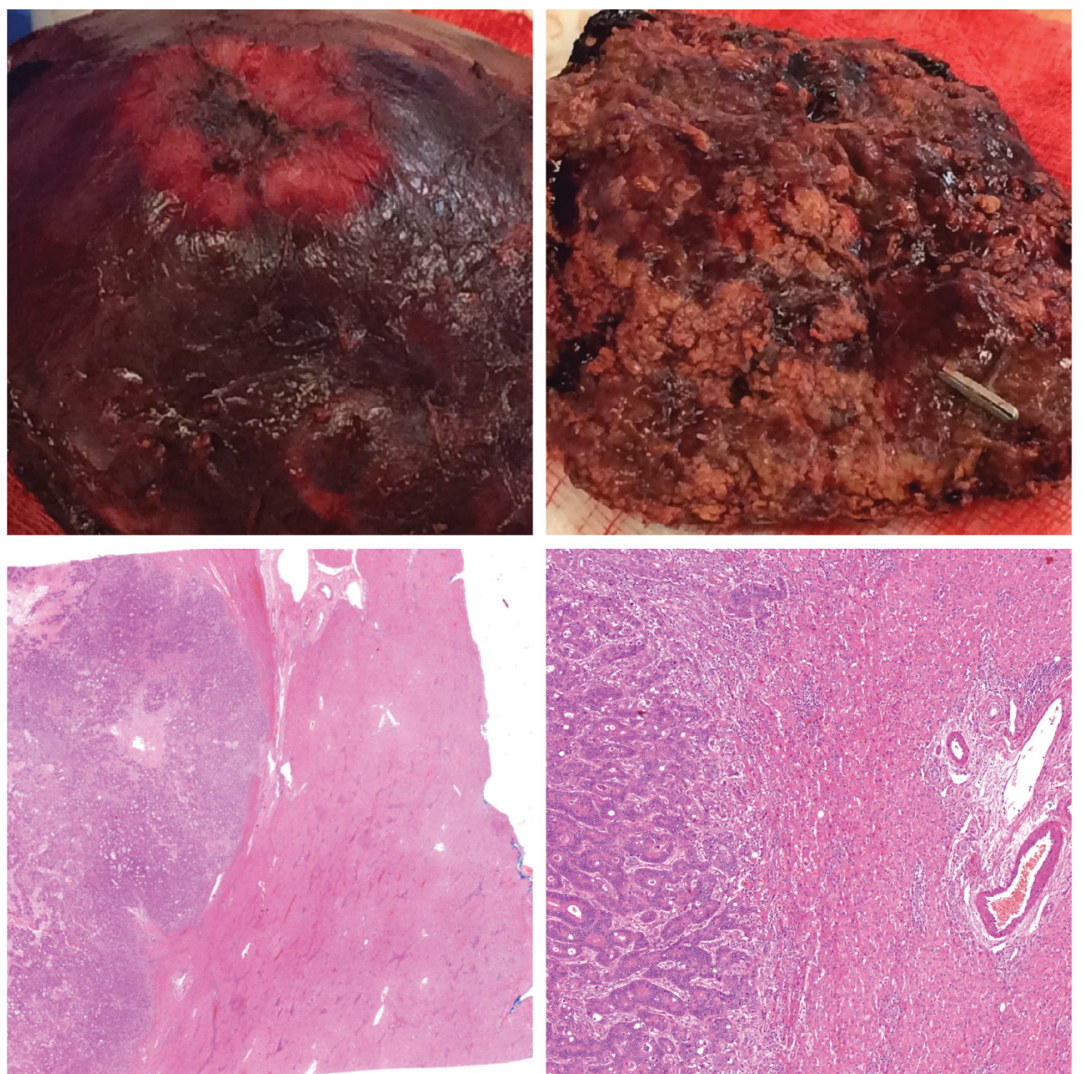

3. ábra

| Az eltávolított májáttét makroszkópos képe (fent) és mikroszkópos metszete (lent) 


\section{Megbeszélés}

A laparoszkópos májreszekciónak, bár nem rutinszerü beavatkozás, van helye az onkológiai betegek ellátásában is, és egyre nagyobb számban végzik világszerte. Magyarországon benignus májelváltozás miatt végzett laparoszkópos beavatkozásról már több munkacsoport is beszámolt $[5,6]$, legnagyobb számban, 31 reszekciós mütétről Kupcsulik és mtsai az I. Sz. Sebészeti Klinikáról 2015-ben [6]. Malignus májdaganatok laparoszkópos reszekciójáról a Magyar Sebész Társaság Endoszkópos Szekciójának 16. Kongresszusán számoltak be az Országos Onkológiai Intézet munkatársai 14 eset kapcsán, illetve HALS-technikával végzett laparoszkópos májreszekcióról tartottak előadást a Kaposvári Kórház Sebészeti Osztályának munkatársai. Malignus májelváltozás tisztán laparoszkópos reszekciójáról magyar nyelvű közleményt eddig nem találtunk.

A nemzetközi összefoglaló és összehasonlító tanulmányok száma meredeken emelkedik, randomizált, kontrollált tanulmányt azonban eddig még nem közöltek a témában, jelenleg várják több futó vizsgálat eredményeit. A tanulmányok alapján a laparoszkópos reszekció eredményei nem rosszabbak a nyílt reszekciós eredményektől sem a primer, sem az áttéti májdaganatok esetében [20-28]. A 2014. októberben, Japánban, Moriokában rendezett, immár második konszenzuskonferencia során több szempont alapján értékelték a laparoszkópos májreszekciók helyzetét [29]. Külön vizsgálták a minor és a major laparoszkópos májreszekciók eredményeit, a megállapításokat most együttesen idézzük:

- A posztoperatív komplikációk tekintetében a laparoszkópos reszekciók eredményei bizonyos területeken jobbak, míg más komplikációk tekintetében nem roszszabbak, mint a nyílt mütétek esetében. Külön kiemelik a cirrhoticus betegeket, akik a posztoperatív ascitesképződés csökkenése miatt profitálhatnak a laparoszkópos megközelítésből.

- A reszekciós szélek vizsgálata alapján a laparoszkópos reszekciós eredmények szintén nem maradnak el a nyílt mútéti eredményektől. Ennél a pontnál kiemelik a tényt, amely szerint nehéz bizonyos esetekben a nyílt mütétekkel összehasonlítani a laparoszkópos eredményeket, hiszen például a nagyérközeli daganatok aránya jelentősen nagyobb a nyílt reszekciók között, így az összehasonlítás nem minden esetben azonos betegségkritériumok között történik.

- A kórházi tartózkodás és a vérvesztés/transzfúziós igény tekintetében egyértelmű a laparoszkópia előnye.

- A túlélés tekintetében nem marad alul a laparoszkópos technika a nyílt mütétekhez képest.

- A posztoperatív fájdalom, kozmetikai eredmények, életminőség, sérvképződés tekintetében bizonyító erejü analízis nem áll rendelkezésre.

Az elöl fekvő szegmentumokban elhelyezkedő, leginkább szoliter elváltozások a legideálisabbak a laparoszkópos reszekcióra, illetve a 2-es és 3-as szegmentumot érin- tő elváltozások esetén indokolt bal lateralis lobectomiát tartják még a technikailag könnyebben kivitelezhető laparoszkópos májreszekciónak. Azonban nem elsősorban a szegmentum, hanem a tumor szegmentumon belüli elhelyezkedése, mérete, nagyerekhez való közelsége és a máj általános állapota határozza meg a tervezhető laparoszkópos reszekció nehézségét.

A laparoszkópos májreszekciók tanulóperiódusát tekintve nehéz egyértelmü kritériumokat megnevezni. Mindenképpen szükség van a nyílt májsebészeti eljárások rutinszerû gyakorlatára, a mind tágabb májsebészeti technikák ismeretére. Azonban a laparoszkópos technika megtanulására és gyakorlására nem a máj a legoptimálisabb szerv, azaz egy komoly laparoszkópos gyakorlat is szükséges. Ezenfelül laparoszkópos reszekciónál az intraoperatív ultrahang kiterjedt és részletes alkalmazása talán még fontosabb, mint a nyílt mútéteknél. Osztályunkon a haladó laparoszkópos beavatkozások mindennapi alkalmazása, a régi hagyományokon alapuló jelentős számú nyílt májreszekciós mútét tapasztalata és több benignus májelváltozás laparoszkópos eltávolítása alapozta meg a malignus elváltozások laparoszkópos reszekciós mütéteit.

Osztályunk elmúlt 10 évének májreszekciós beteganyagát áttekintve azt feltételezzük, hogy a nehezebben megközelíthető szegmentumokat érintő, potenciálisan laparoszkóposan ellátható daganatokat is számolva, a közeljövőben maximum a betegek $20 \%$-ánál tervezhető minor laparoszkópos reszekció (elsősorban szoliter, nem túl mélyen elhelyezkedő, maximum 2 szegmentum reszekcióját igénylő elváltozások). Major reszekciót nagyobb minor reszekciós esetszám elérése után tervezünk.

Véleményünk szerint, bár nem érezzük magunkat a technikában rutinosnak, a nehezebben megközelíthető malignus májelváltozások minimálisan invazív eltávolítása is kivitelezhető, és egyértelmüen kimondható, hogy nem kísérleti eljárásokról vagy technikai bravúrról van szó, amikor laparoszkópos májreszekcióról beszélünk.

Anyagi támogatás: A közlemény megírása anyagi támogatásban nem részesült.

Szerzôi munkamegosztás: D. K. írta a közleményt és végezte a mútétet. P. G. segített a mútét során. S. F. végezte a patológiai vizsgálatot és készítette a metszetek képeit. U. A. részt vett az eset kezelésében. B. A. teremtette meg a mütét körülményeit, és segített a kézirat elkészítésében. A cikk végleges változatát valamennyi szerző elolvasta és jóváhagyta.

Érdekeltségek: A szerzőknek nincsenek érdekeltségeik.

\section{Köszönetnyilvánítás}

Köszönet Dr. Ivanecz Árpádnak, akinek vendégeként hasznos szakmai tanácsokkal gazdagodhattunk a Maribori Sebészeti Klinikán. 


\section{Irodalom}

[1] Reich, H., McGlynn, F., DeCaprio, J., et al.: Laparoscopic excision of benign liver lesions. Obstet. Gynecol., 1991, 78(5), 956-958.

[2] Vibert, E., Kouider, A., Gayet, B.: Laparoscopic anatomic liver resection. HPB (Oxford), 2004, 6(4), 222-229.

[3] Viganò, L., Tayar, C., Laurent, A., et al.: Laparoscopic liver resection: a systematic review. J. Hepatobiliary Pancreat. Surg., 2009, $16(4), 410-421$.

[4] Kazaryan, A. M., Pavlik Marangos, I., Rosseland, A. R., et al. Laparoscopic liver resection for malignant and benign lesions: ten-year Norwegian single-center experience. Arch. Surg., 2010, 145(1), 34-40.

[5] Kánya, L., Botos, A., Bezsilla, J., et al.: Laparoscopic surgery of focal lesions of the liver. Acta Chir. Hung., 1999, 38(2), 187189

[6] Kupcsulik, P., Hahn, O., Szijártó, A., et al.: Laparoscopic surgery of benign liver tumours. [Benignus májdaganatok laparoszkópos resectiója.] Magy. Seb., 2015, 68(1), 3-7. [Hungarian]

[7] Kupcsulik, P.: Laparoscopic liver surgery. [Laparoszkópos májresectiók.] Magy. Seb., 2014, 67(4), 243-251. [Hungarian]

[8] Lin, N. C., Nitta, H., Wakabayashi, G.: Laparoscopic major hepatectomy: a systematic literature review and comparison of 3 techniques. Ann. Surg., 2013, 257(2), 205-213.

[9] Hasegawa, Y., Koffron, A. J., Buell, J. F., et al.: Approaches to laparoscopic liver resection: a meta-analysis of the role of handassisted laparoscopic surgery and the hybrid technique. J. Hepatobiliary Pancreat. Sci., 2015, 22(5), 335-341.

[10] Bueno, A., Rotellar, F., Benito, A., et al.: Laparoscopic limited liver resection decreases morbidity irrespective of the hepatic segment resected. HPB (Oxford), 2014, 16(4), 320-326.

[11] Ikeda, T., Toshima, T., Harimoto, N., et al.: Laparoscopic liver resection in the semiprone position for tumors in the anterosuperior and posterior segments, using a novel dual-handling technique and bipolar irrigation system. Surg. Endosc., 2014, 28(8), 2484-2492.

[12] Abu Hilal, M., van der Poel, M. J., Samim, M., et al.: Laparoscopic liver resection for lesions adjacent to major vasculature: feasibility, safety and oncological efficiency. J. Gastrointest. Surg., $2015,19(4), 692-698$

[13] Ferrero, A., Lo Tesoriere, R., Russolillo, N., et al.: Ultrasoundguided laparoscopic liver resections. Surg. Endosc., 2015, 29(4), 1002-1005

[14] Palanisamy, S., Sabnis, S. C., Patel, N. D., et al.: Laparoscopic major hepatectomy-technique and outcomes. J. Gastrointest. Surg., 2015, 19(12), 2215-2222.

[15] Benzing, C., Krenzien, F., Atanasov, G., et al.: Single incision laparoscopic liver resection (SILL) - a systematic review. GMS Interdiscip. Plast. Reconstr. Surg. DGPW, 2015, 4, Docl7.

[16] Chiow, A. K., Lewin, J., Manoharan, B. et al.: Intercostal and transthoracic trocars enable easier laparoscopic resection of dome liver lesions. HPB (Oxford), 2015, 17(4), 299-303.
[17] Ogiso, S., Conrad, C., Araki, K., et al.: Laparoscopic transabdominal with transdiaphragmatic access improves resection of difficult posterosuperior liver lesions. Ann. Surg., 2015, 262(2), 358-265.

[18] Ho, C. M., Wakabayashi, G., Nitta, H., et al.: Systematic review of robotic liver resection. Surg. Endosc., 2013, 27(3), 732-739.

[19] Montalti, R., Berardi, G., Patriti, A., et al.: Outcomes of robotic vs. laparoscopic hepatectomy: A systematic review and metaanalysis. World J. Gastroenterol., 2015, 21(27), 8441-8451.

[20] Buell, J. F., Cherqui, D., Geller, D. A., et al.: The international position on laparoscopic liver surgery: The Louisville Statement, 2008. Ann. Surg., 2009, 250(5), 825-830.

[21] Cheung, T. T., Poon, R. T., Yuen, W. K., et al.: Long-term survival analysis of pure laparoscopic versus open hepatectomy for hepatocellular carcinoma in patients with cirrhosis: a single-center experience. Ann. Surg., 2013, 257(3), 506-511.

[22] Zhou, $\Upsilon$., Xiao, $\Upsilon$., Wu, L., et al.: Laparoscopic liver resection as a safe and efficacious alternative to open resection for colorectal liver metastasis: a meta-analysis. BMC Surg., 2013, 13, 44.

[23] Alkhalili, E., Berber, E.: Laparoscopic liver resection for malignancy: A review of the literature. World J. Gastroenterol., 2014, 20(37), 13599-13606

[24] Iwahashi, S., Shimada, M., Utsunomiya, T., et al.: Laparoscopic hepatic resection for metastatic liver tumor of colorectal cancer: comparative analysis of short- and long-term results. Surg. Endosc., 2014, 28(1), 80-84.

[25] Memeo, R., de'Angelis, N., Compagnon, P., et al.: Laparoscopic vs. open liver resection for hepatocellular carcinoma of cirrhotic liver: a case-control study. World J. Surg., 2014, 38(11), 29192926.

[26] Montalti, R., Berardi, G., Laurent, S., et al.: Laparoscopic liver resection compared to open approach in patients with colorectal liver metastases improves further resectability: Oncological outcomes of a case-control matched-pairs analysis. Eur. J. Surg. Oncol., 2014, 40(5), 536-544.

[27] Postriganova, N., Kazaryan, A. M., Røsok, B. I., et al.: Margin status after laparoscopic resection of colorectal liver metastases: does a narrow resection margin have an influence on survival and local recurrence? HPB (Oxford), 2014, 16(9), 822-829.

[28] De'Angelis, N., Eshkenazy, R., Brunetti, F., et al.: Laparoscopic versus open resection for colorectal liver metastases: a singlecenter study with propensity score analysis. J. Laparoendosc. Adv. Surg. Tech. A, 2015, 25(1), 12-20.

[29] Wakabayashi, G., Cherqui, D., Geller, D. A., et al.: Recommendations for laparoscopic liver resection: a report from the second international consensus conference held in Morioka. Ann. Surg., $2015,261(4), 619-629$. 